\title{
Alternative Rice Straw Management Practices to Reduce Field Open Burning in Thailand
}

\author{
K. Kanokkanjana and S. Garivait
}

\begin{abstract}
Open burning of rice straw causes release of air pollutants, which contributes to enhance climate change related issues. Moreover, the burning practice was a reason of losing carbon content from crop land to the atmosphere. This study focuses on estimation of carbon content loss to the atmosphere through open burning of rice straw and suggests alternative rice straw management practices to reduce field open burning in Thailand. Field experiments were conducted to collect samples of rice straw to quantify residue to product ratio (RPR) and analyze their carbon content by elemental analysis. Ash samples were also collected to analyze their carbon content. Carbon losses to the atmosphere through field burning were then estimated. To better understand traditional practices of open burning in Thailand, statistics related to seasonal rice production/harvesting were also investigated. Finally, economic and environmental benefits associated to alternative rice straw management options were considered and discussed against traditional open burning practices.
\end{abstract}

Index Terms - Rice straw, residue to product ratio, field open burning, carbon released.

\section{INTRODUCTION}

Open burning of biomass is a serious problem in Thailand, especially in dry season. In April to May, thick smoke haze could be detected by satellite and the monitoring maximum concentration of 24-hr average $\mathrm{PM}_{10}$ in north region exceeded the National Ambient Standard $\left(120 \mu \mathrm{g} / \mathrm{m}^{3}\right)$. The government has tried to control this problem by set up National policies and plans to control fire and haze i.e. National Master Plan for Open Burning Control (2005), National Action Plan on Fire and Haze Control (2012-2017), National Fire and Haze Control Plan of Action (2013), and so on. Major sources of smoke and haze problem were forest fire, agricultural fire, and open burning of waste [1]. This study focuses on a source of agricultural fire, which is open burning of rice straw in paddy fields.

Following harvesting of rice, there are various practices to clear the land for next cultivation. The common practice is burning, which is the most convenient, cheapest, and fastest way to eliminate rice straw, especially in irrigated paddy field. Burning of rice straw in the field releases pollutants to the atmosphere and contributes to enhance global problems such as climate change. During burning, carbon is released into the air in various forms. Major fractions of carbon released from

Manuscript received December 5, 2012; revised February 6, 2013. This work was supported in part by the Joint Graduate School of Energy and Environment, and Petch Phrachomklao King Mongkut's University of Technology Thonburi.

The authors are with the Joint Graduate School of Energy and Environment, Bangkok, Thailand (e-mail: kkanittha@yahoo.com, savitri@jgsee.kmutt.ac.th). crop burning consist of $\mathrm{CO}_{2}\left(1,515 \pm 117 \mathrm{~g} / \mathrm{kg}_{\mathrm{dm}}\right)$, $\mathrm{CO}(92 \pm 84$ $\left.\mathrm{g} / \mathrm{kg}_{\mathrm{dm}}\right)$, TC $\left(4 \mathrm{~g} / \mathrm{kg}_{\mathrm{dm}}\right)$, and $\mathrm{CH}_{4}\left(2.7 \mathrm{~g} / \mathrm{kg}_{\mathrm{dm}}\right)$ [2]. These air pollutants contribute to enhance climate change [3], [4]. Although biogenic carbon is emitted to the atmosphere as a result of open burning, the $\mathrm{CO}_{2}$ fraction is reabsorbed via photosynthesis in the next cultivation in the form carbon biomass. However this is not the case for other forms of carbon such as $\mathrm{CO}$, TC or $\mathrm{CH}_{4}$. Therefore in this study the amount of carbon loss to the atmosphere is also accounted for.

In this study, benefits from alternative rice straw management practices are also analyzed to serve as a guideline for good management practices after rice harvesting.

\section{MAterials AND MEthodS}

\section{A. Field Experiments in the Paddy Fields}

Field experiments were conducted in paddy field in irrigated and non-irrigated areas. At the study sites, rice was cultivated by broadcast and harvested by machine. In irrigated areas, rice can be cultivated more than once a year. The cultivation is done during the rainy season, called "major rice” and off-rainy season, called "second rice.” Experiments were carried out for both major rice and second rice. In non-irrigated areas, water from rain is relied upon so that rice can only be cultivated once a year during the rainy season, called "major rice." However, in areas where there are sufficient resources in natural water, rice can also be planted during the dry season, called "second rice."

Samples of rice straw were collected to determine the residue to product ratio (RPR) which is obtained by dividing the dry weight of rice straw with that of paddy rice. This study focuses on rice straw burning, the top part of residues which mostly burn after harvesting. To quantify dry weight, the samples were dried at $70^{\circ} \mathrm{C}$ (to remain carbon component) for at least $24 \mathrm{hr}$ until the weight was stable. After burning, samples of ash were collected to consider dry weight and carbon content.

Overall, the amount of rice straw in the country was quantified by multiplying the RPR obtained from field experiments with rice production statistics in Thailand [5]. The base year of this study is 2010 because cultivation of rice in this year followed normal practice; there was no severe flood or drought in the selected year.

\section{B. Analysis of Carbon Content}

Rice straw and ash samples were analyzed for their carbon content by ultimate analysis. The experiments were conducted by thermal method with Elemental Analyzer 
(Thermo Fisher Scientific, Model Flash EA 1112 NC Series, UK). Helium was used as carrier gas. The chemical standard was BBOT, containing 6.51\%N, $72.53 \% \mathrm{C}$, and $6.09 \% \mathrm{H}$. Approximate $4 \mathrm{mg}$ of samples were analyzed in each batch with three replicate. Operated temperature of the EA machine was at $950{ }^{\circ} \mathrm{C}$.

\section{Carbon Released from Open Burning of Rice Straw}

Results of ultimate analysis were applied in the following equation to determine the amount of carbon released to the atmosphere.

$$
C_{\text {released }}=C_{\text {burned }}-C_{\text {ash }}
$$

Quantity of carbon released from open burning of rice straw $\left(C_{\text {released }}\right)$ was obtained by subtracting amount of carbon that remain in ash after burning $\left(C_{a s h}\right)$ from carbon content contained in burned rice straw $\left(C_{\text {burned }}\right)$. To obtain $\mathrm{C}_{\text {burned }}$ and $\mathrm{C}_{\mathrm{ash}}$, percentage of carbon content in rice straw and ash from ultimate analysis results were multiplied with dry weight of rice straw and ash.

In order to estimate total amount of $\mathrm{C}_{\text {released }}$ from open burning of rice straw based on season of burning in Thailand, data on quantity of rice straw produced and fraction burned in the field were retrieved from secondary sources [6].

\section{Economic Analysis}

Benefits to farmers from selling rice straw were also investigated in this study. Information on the local price of rice straw was collected via interviews of farmers at the study sites and also based on secondary data. Straw utilization is categorized into two types, loose rice straw and baled rice straw (rectangular shape).

\section{RESULTS AND DISCUSSIONS}

\section{A. Total Amount of Rice Straw in Thailand}

Total amount of rice straw (Table I) was quantified based on results of field experiments, residue-to-production ratio (RPR), and statistics of rice production. For major rice, production data is from 2009/2010, over the period August 2009 to April 2010. For second rice, production data is from 2010/2011, over the period February 2010 to October 2010 [5].

TABLE I: TOTAL AMOUNT OF RICE STRAW IN THAILAND, 2010

\begin{tabular}{llcc}
\hline \hline Categories & RPR & $\begin{array}{c}\text { Products } \\
\text { (million tons/y) }\end{array}$ & $\begin{array}{c}\text { Rice straw } \\
\text { (million tons/y) }\end{array}$ \\
\hline $\begin{array}{l}\text { Irrigated (major) } \\
\text { Irrigated (second) }\end{array}$ & $1.06 \pm 0.55$ & 8.14 & $8.63 \pm 4.48$ \\
$\begin{array}{l}\text { Non-irrigated } \\
\text { (major) }\end{array}$ & $0.55 \pm 0.11$ & 6.64 & $4.32 \pm 1.86$ \\
$\begin{array}{l}\text { Non-irrigated } \\
\text { (second) }\end{array}$ & - & 15.11 & $8.31 \pm 1.66$ \\
\hline \hline
\end{tabular}

There are no results for RPR of second rice at the non-irrigated paddy field. Hence the RPR value of major rice at the same area was applied to estimate the amount of rice straw produced in non-irrigated area (second rice).

The total amount of rice straw produced was found to amount to 23 million tons annually, including 13 million tons from irrigated paddy fields and 10 million tons from non-irrigated paddy fields. The RPR in irrigated paddy fields was found to be lower than the RPR in non-irrigated paddy fields mainly because of the lower yield at the study sites. The varieties of rice cultivated in major and second rice were different so periods of planting to harvesting were also different. The major rice varieties required longer period of cultivation than the second rice varieties, consequently, larger amounts of biomass were produced in the paddy fields where major rice varieties were planted. Hence, the largest sources of rice straw were found to be the major rice varieties that are planted in irrigated areas. These are mainly located in the central part of the country. The smallest sources of rice straw were found to be the second rice varieties that are cultivated in non-irrigated areas. As non-irrigated areas rely mainly on natural resources of water, rain essentially, major rice was mostly cultivated; only few areas had second rice. Therefore, areas of second rice plantation in non-irrigated areas were small, another reason for the low amount of straw found to be produced in such areas during the dry season.

\section{B. Amount of Burned Rice Straw in the Field}

The quantity of rice straw burned in paddy fields were estimated based on the quantity of rice straw found to be produced in this study and the fraction that is burned in the field based on secondary information [6]. The results are presented in Table II along with the amount of ash generated from open burning of rice straw.

TABLE II: OPEN BURNING OF RICE STRAW IN THE FIELD

\begin{tabular}{lclll}
\hline \hline & $\begin{array}{l}\text { Fraction } \\
\text { of burned } \\
\text { rice straw } \\
\text { Categories }\end{array}$ & $\begin{array}{l}\text { Burned rice } \\
\text { straw } \\
\text { (million } \\
\text { tons/y) }\end{array}$ & $\begin{array}{l}\text { \% ash in } \\
\text { burned } \\
\text { straw }\end{array}$ & $\begin{array}{l}\text { Ash } \\
\text { (thousand } \\
\text { tons/y) }\end{array}$ \\
\hline $\begin{array}{l}\text { Irrigated(major) } \\
\begin{array}{l}\text { Irrigated } \\
\text { (second) }\end{array}\end{array}$ & $49 \pm 2$ & $4.23 \pm 2.20$ & $15.87 \pm 0.88$ & $672 \pm 348$ \\
$\begin{array}{l}\text { Non-irrigated } \\
\text { (major) }\end{array}$ & $20 \pm 3$ & $1.65 \pm 0.33$ & $24.70 \pm 3.07$ & $408 \pm 82$ \\
$\begin{array}{l}\text { Non-irrigated } \\
\text { (second) }\end{array}$ & $41 \pm 8$ & $0.79 \pm 0.16$ & - & $196 \pm 39$ \\
\hline \hline
\end{tabular}

From Table II, the amount of rice straw burned in the field after harvesting is found to amount to 10.41 million tons for the year 2010. Major burned areas concern paddy fields located in irrigated areas accounting for $77 \%$ of the total amount of rice straw burned, the remaining $23 \%$ coming from burning in non-irrigated areas. Of the $23 \%$, only $8 \%$ is contributed by rice straw burning after harvesting second rice. After harvesting rice in irrigated paddy fields, farmers promptly prepare the land for the next cultivation. The fallow period in irrigated paddy fields is therefore quite short, about 1 to 2 weeks. Because of abundant water resources availability, rice in irrigated paddy fields can be cultivated continuously throughout the year. The most convenient, cheapest, and fastest way to eliminate rice straw to clear the land is combustion. Therefore, open burning is mainly found in irrigated areas.

The total amount of ash generated from open burning in paddy fields was found to amount to $2.05 \pm 0.80$ million tons, which represents $20 \%$ of the total amount of rice straw 
burned. Therefore, the quantity of mass lost from the combustion process is $80 \%$, released into the atmosphere in the form of gaseous and particulate matters. Following the assessment of the amount of biomass consumed as a result of rice straw burning, this study focuses on its carbon content as carbon is an important component contributing to climate change.

\section{Carbon Released from Open Burning in the Paddy Field}

The results of carbon analysis showed that there were $40 \% \mathrm{C}$ by mass $( \pm 0.7 \% \mathrm{C}$, SD) in rice straw and $17 \% \mathrm{C}$ by mass $( \pm 1.5 \% \mathrm{C}, \mathrm{SD})$ in ash. From the carbon analysis results, the amount of carbon in rice straw, burned rice straw, and ash could be estimated. In addition, the quantity of carbon released from open burning of rice straw was calculated as presented in Table III.

TABLE III: CARBON CONTENT IN RICE STRAW, BURNED RICE STRAW, ASH, AND CARBON RELEASED TO THE ATMOSPHERE FROM OPEN BURNING OF

\begin{tabular}{lcccc}
\multicolumn{5}{c}{ RICE STRAW IN THE FIELD } \\
\hline \hline Categories & $\begin{array}{l}\text { C rice straw } \\
\text { (million } \\
\text { tons/y) }\end{array}$ & $\begin{array}{l}\text { C burned } \\
\text { (million } \\
\text { tons/y) }\end{array}$ & $\begin{array}{l}\text { C ash } \\
\text { (thousand } \\
\text { tons/y) }\end{array}$ & $\begin{array}{l}\text { C released } \\
\text { (million } \\
\text { tons/y) }\end{array}$ \\
\hline $\begin{array}{l}\text { Irrigated } \\
\text { (major) }\end{array}$ & $3.47 \pm 1.80$ & $1.70 \pm 0.88$ & $117 \pm 61$ & $1.58 \pm 0.82$ \\
$\begin{array}{l}\text { Irrigated } \\
\text { (second) }\end{array}$ & $1.74 \pm 0.75$ & $1.50 \pm 0.65$ & $135 \pm 58$ & $1.37 \pm 0.59$ \\
$\begin{array}{l}\text { Non-irrigated } \\
\text { (major) }\end{array}$ & $3.34 \pm 0.67$ & $0.66 \pm 0.13$ & $71 \pm 14$ & $0.59 \pm 0.12$ \\
$\begin{array}{l}\text { Non-irrigated } \\
\text { (second) }\end{array}$ & $0.77 \pm 0.15$ & $0.32 \pm 0.06$ & $34 \pm 7$ & $0.29 \pm 0.06$ \\
\hline Total & $9.32 \pm 3.37$ & $4.19 \pm 1.73$ & $358 \pm 140$ & $3.83 \pm 1.59$ \\
\hline \hline
\end{tabular}

From Table III, total amount of carbon contained in the rice straw was found to amount to $9.32 \pm 3.37$ million tons $\mathrm{C}$ and in burned rice straw to $4.19 \pm 1.73$ million tons $C$. The remaining carbon in ash that would be back to the land amounts to $358 \pm 140$ thousand tons $C$ and the fraction released to the atmosphere to $3.83 \pm 1.59$ million tons $\mathrm{C}$. As major areas of paddy fields burned were found in irrigated rice fields, consequently, largest amounts of carbon were found to be released from irrigated paddies during major and second rice cultivation, respectively.

The fraction of carbon released to the atmosphere that can be recycled via photosynthesis as carbon biomass in the next crop is that corresponding to $\mathrm{CO}_{2}$. According to [7] the corresponding percentage of $\mathrm{C}_{\mathrm{CO} 2}$ that can be re-incorporated into biomass via such process is 93\% translating into $3.56 \pm 1.48$ million tons $C$. Therefore, the net amount of carbon released to the atmosphere from open burning of rice straw would amount to $268 \pm 111$ thousand tons C. Most other forms of carbon released are $\mathrm{CO}$, TC (BC and $\mathrm{OC})$, and $\mathrm{CH}_{4}$ [2]. These gases $\left(\mathrm{CO}\right.$ and $\left.\mathrm{CH}_{4}\right)$ and aerosols (BC and OC) contribute to enhance climate change; however, the problems could be avoided by suitable management practices of rice straw.

\section{Season of Harvesting in Thailand}

As observed from Fig. I, period of rice harvesting varies depending on rice varieties. The harvesting season of major rice is mainly found during the dry season, while second rice is observed during the wet season. Production of major rice spans over the period August to May of the next year. The highest production is found in November. Lowest production is observed during February - April.

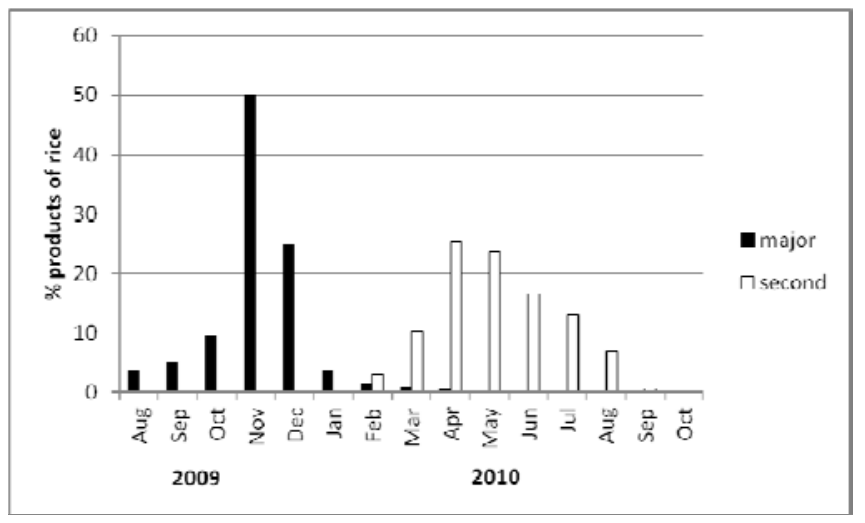

Fig. 1. Harvesting season of major and second rice in Thailand, 2009/2010.

Second rice is harvested during February - October. The period of major rice and second rice harvesting overlaps over the period February - April, which correspond to the late harvesting season of major rice and early harvesting season of second rice. Although rice harvesting is lower during this period, serious haze problems are usually observed during this time. This is mainly because of open burning from other sources i.e. forest fires, waste incinerations, and open burning of other agricultural residues [1]. February to April is the period corresponding to the dry season in Thailand, time during which relative humidity is at its lowest and good conditions for ignition of vegetation at their highest. Hence, open burning activities should be carefully monitored and controlled in that time.

\section{E. Alternative Rice Straw Management Practices}

In order to identify suitable management practices of rice straw in Thailand and reduce open field burning, information were collected from farmers via interviews and combined with other data from secondary sources.

The prohibited period of open burning in Thailand would be from January to April because of serious smoke and haze problems, especially in the northern region. The National Fire and Haze Control Plan of Action (2013) was announced to control open burning in nine provinces of the northern region of the country during January 21 to April 10, 2013 [1]. Due to dry weather, the quality of straw was good because the straw contained low moisture. There was no problem of fungi in dry straw. In addition, the soil in the paddy field was dried and hard enough for a large machine, a straw baler, to collect straw in the field. Social benefit of collecting straw out of the field was considered.

Cost and benefit of selling straw during dry season were analyzed. Most straw was sold by two ways, loose straw and baled straw. The loose straw would be sold directly to the consumer that would collect in the field by themselves and transport by pickup truck. The loose straw was mainly used in agricultural area, i.e. mulching young plants. Price of the straw would be per area (4.17-10.42 USD/ha, 30 THB/USD). Advantage of selling loose straw was no cost of straw collecting. Disadvantage of selling loose straw was only small amount collected because of huge volume of loose straw. 
Farmers also sold the baled straw that was collected by the straw baler. The owner of the baler machine is an intermediate merchant that would buy the baled straw from the farmers and sell to the customers. The cost of the baled straw consists of the cost of baling (15-20 THB/pack) and cost of moving baled straw out of the field (3-5 THB/pack). The benefit of selling the baled straw was analyzed per pack. The weight of the baled straw is $10-15 \mathrm{~kg} / \mathrm{pack}$. The advantage of selling the baled straw is high benefit. The disadvantage is the lack of straw baler in Thailand. A comparison of cost-benefit between the loose straw and the baled straw is presented in Table IV.

TABLE IV: COST AND BENEFIT OF RICE STRAW

\begin{tabular}{lcc}
\hline \hline Categories & Cost (USD/thousand tons) & Benefit (USD/thousand tons) \\
\hline $\begin{array}{l}\text { Loose straw } \\
\text { Baled straw } \\
\text { (dry season) }\end{array}$ & - & $1.36-2.05$ \\
$\begin{array}{l}\text { Baled straw } \\
\text { (wet season) }\end{array}$ & $48,000-66,667$ & $109,333-146,667$ \\
\hline \hline
\end{tabular}

Note: 30 THB/USD

From Table IV, the highest net benefit is form selling the baled straw produced during the dry season. The cost of baling rice straw is the same between wet and dry seasons; however, the benefit is different because abundant grass was available for feedstock during the wet season so the demand for baled straw was low during this time. High demands of baled straw were found during the dry season so the price was nearly double. Net benefits (benefit minus cost) from selling straw were found to amount to 1.36-2.05 USD/thousand tons of loose straw, 18,667-40,000 USD/thousand tons of baled straw (wet season), and 61,333-80,000 USD/thousand tons of baled straw (dry season), respectively.

Although loose straw gains the lowest net benefit, most farmers sell loose straw as straw baler is scarce in Thailand. Thai engineers could produce straw baler but the baling machine requires labor for manual fastening by rope and so it is not widely used. Most intermediate merchants buy second hand automatic machines imported from other countries because they require little labor and operate more quickly [8].

The main reason of burning rice straw in the field instead of selling is that it is difficult to manage and requires transport of large volumes of rice straw. Although straw can be baled into a compressed pack, the volume is still too high for transport by truck without issues of illegal overloading.

Although open burning of rice straw contributes to release pollutants to the atmosphere, the combustion also provides some benefits. The open burning may help to remove insects and diseases from the field. The remaining ash left in the field after burning may enable to adjust soil $\mathrm{pH}$ and improve soil texture, useful for rice cultivation. Therefore, open burning could be done during May to October because the released gases and aerosols would be deposited back into the soil through raining. In addition, straw collection by machine during this period is difficult because of wet soil. Moreover, wet straw could not be stored because of fungi problem.

The period November to December is the season of major rice harvesting in non-irrigated paddy fields. As the fallow period for the non-irrigated paddy fields is quite long (rice is usually cultivated only once), therefore, the generated straw should be ploughed back into the soil as organic amendment to improve soil quality.

The rice straw should be collected for various utilizations i.e. feedstock, material for furniture manufacturer/home building, handicraft, media for mushroom cultivation, mulching in the garden, decorating places, and so on. These utilizations could gain value of rice straw instead of burning that released carbon into the atmosphere for $47.36 \%$.

\section{CONCLUSIONS}

Open burning of rice straw in the paddy fields releases pollutants into the atmosphere that contribute to enhance climate change issues. Alternative management options for rice straw have been suggested in this study including to collect the straw in dry season (January to April), burn in wet season (May to October), and plow the straw into the soil in non-irrigated paddy fields (November to December). The alternative practices of rice straw management thereby identified could enable reducing the amount of straw burned in the field from $10.41 \pm 4.29$ million tons to $4.89 \pm 2.34$ million tons. The released carbon would also be reduced from $3.83 \pm 1.59$ million tons $\mathrm{C}$ to $1.81 \pm 0.87$ million tons $\mathrm{C}$ including $\mathrm{C}_{\mathrm{CO} 2} 1.69 \pm 0.81$ million tons $\mathrm{C}$ and other carbon forms totaling $0.13 \pm 0.06$ million tons $\mathrm{C}$.

\section{ACKNOWLEDGMENTS}

K. K. and S.G. Authors express their gratitude to the Joint Graduate School of Energy and Environment, King Mongkut's University of Technology Thonburi and the Center for Energy Technology and Environment, Ministry of Education Thailand, for financial support. The Earth Systems Science Research and Development Center, Petch Phrachomklao King Mongkut's University of Technology Thonburi, and the Higher Education Research Promotion and National Research University Project of Thailand are highly appreciated for their research fund support. K. K. and S.G. Authors extend further appreciation to Dr. Sebastien Bonnet, the Aerosol from Biomass Burning to the Atmosphere Research Group (ABBA), the field experiment team, and the farmers at the studied sites for their contributions to this work.

\section{REFERENCES}

[1] Pollution Control Department of Thailand, “Thailand Country Report: Land and Forest Fire and Haze Situation in 2012 and Preparations for 2013,” presented at the Joint Graduate School of Energy and Environment, Bangkok, Thailand, December 4, 2012.

[2] M. O. Andreae and P. Merlet, "Emission of trace gases and aerosols from biomass burning,” Global Biogeochemical Cycles, vol. 15, no. 4, pp. 955-966, December 2001.

[3] J. S. Levine, Biomass Burning and Global Change, $1^{\text {st }}$ ed., London, England: The MIT Press, Introduction, pp. xxxv-x1iii, 1996.

[4] M. O. Andreae and P. J. Crutzen, "Atmospherice Aerosols: Biogeochemical Sources and Role in Atmospheric Chemistry,” Science, vol. 276, pp. 1052-1058, May 1997.

[5] Office of Agricultural Economics of Thailand, "Thailand Country Report: Fundamental Agricultural Statistics 2010,” 2011.

[6] P. Cheewapongphan and S. Garivait, "Greenhouse gases emission from rice field residues open burning,” Proc. 1st National Carbon Neutral Conf., pp. 501-511, Nonthaburi, Thailand, 2010. 
[7] K.. Kanokkanjana and S. Garivait, "Carbon Released from Open Burning of Agricultural Residues in Thailand," presented at the iLEAPS SC- Science Conference, Garmisch-Partenkirchen Congress Centre, Germany, September 18-23, 2011.

[8] A. Bridhikitti and K. Kanokkanjana, "Sustainable rice straw management for urban air pollution reduction in bang Bua Thong Nonthaburi Province, Thailand," Case Study Series: ADP 5/2009, pp. 1-23, R. Perera, Ed. Thailand: Asian Institute of Technology, 2009.

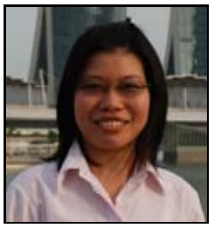

Kanittha K. was born in Bangkok, Thailand on April 6 1979. Educational backgrounds of K. K. are Master of Science in Environmental Engineering and Management from Asian Institute of Technology (AIT), Patumthani, Thailand; Bachelor of Science in Environmental Resources Chemistry from King Mongkut's Institute of Technology Ladkrabang
(KMITL), Bangkok, Thailand; and Bachelor of Economics from Ramkhamhaeng University (RU), Bangkok, Thailand.

Currently, she is a Ph. D. Candidate in Environmental Technology at The Joint Graduate School of Energy and Environment (JGSEE), the Center for Energy Technology and Environment (CEE) located at King Mongkut's University of Technology Thonburi (KMUTT) in Bangkok, Thailand. Research interests concern atmospheric environment. Current research interest is emissions released from open burning of agricultural residues. Previous research interest is simulating dispersion air quality models at point sources in industrial areas.

Miss Kanittha got First class honored when graduated Bachelor degree, scholarship granted by Her Majesty the Queen during Master degree, Fellowship granted by The Joint Graduate School of Energy and Environment (JGSEE); and research fund granted by Earth System Science (ESS), National Research University (NRU), and Petch Phrachomklao (KMUTT) during Ph.D. candidate. 